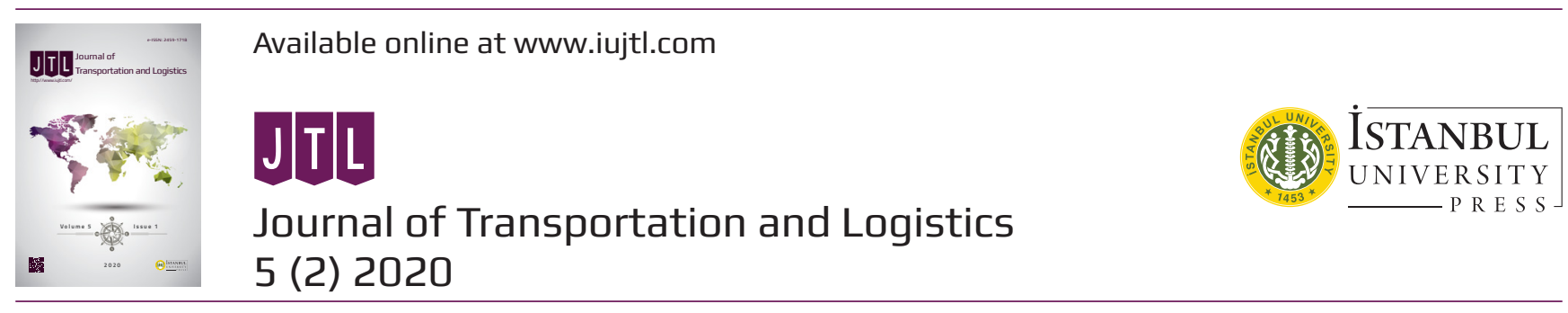

\title{
Examination of the Operating Costs and Environmental Impact of Alternative Fuels Used in Ships
}

\author{
Gemilerde Kullanılan Alternatif Yakıtların İșletme Maliyetleri ve Çevresel Etkilerinin \\ Incelenmesi
}

\author{
Tarik Kocal ${ }^{1}$ (1)
}

\begin{abstract}
Nowadays, transportation has reached dimensions that have never been seen before, the amount of cargoes has diversified with quantity increases with the development of industry. Low cost, the number of goods transported, and security are the most important factors in the transportation sector. Due to these reasons, the majority of cargo transport in the world is carried out by seaway. In addition, the high increases in the costs of diesel fuel in ship transportation lead shipowners to use different fuels. Alternative fuels have started to be used on new ships and certain old ships. In this study in a one-year period, the costs and carbon dioxide emission values of alternative fuels that can be used in ships were calculated in different operating conditions. The ship used in this study has a diesel engine with a power of $5975 \mathrm{~kW}$ at full load. The costs of using LNG, LPG and methanol fuels as an alternative to diesel fuel (HFO, MDO) in the selected engine are calculated according to different load conditions and different annual working hours. When the results of the calculations are examined, it is seen which fuel could be more economical and environment friendly. Keywords: Alternative Fuel, Annual Carbon Dioxide Release, Cost, Emission, Transportation
\end{abstract}

Öz

Sanayinin gelişmesiyle ticareti yapılan yüklerin çeşitlenerek miktarının arttığı günümüzde, taşımacılık geçmişte hiç olmadığı kadar büyük boyutlara ulaşmıştır. Düşük maliyet, taşınan mal miktarı ve güvenlik taşımacılık sektöründe en önemli unsurlardır. Bu nedenlerden dolayı dünyadaki yük taşımacılığının büyük bir kısmı deniz yoluyla yapılmaktadır. Deniz taşımacılığı diğer taşımacılık türlerine göre daha çevrecidir. Ancak uluslararası ticaret hacminin ve dolayısıyla gemi sayılarının artışı, gemi kaynaklı emisyon miktarlarını arttırmıştır. Bu açıdan bakıldı̆ında gemi emisyonları konusu irdelenmesi gereken önemli bir konu haline gelmiştir. Ayrıca gemi taşımacılığında dizel yakıtın maliyetlerinde meydana gelen yüksek artışlar armatörleri farklı yakıtları kullanmaya yönelmelerine neden olmuştur. Yeni yapılan gemilerde ve bazı eski gemilerde revizyon yapılarak alternatif yakıtlar kullanılmaya başlanmıştır. Bu çalışmada gemilerde kullanılabilecek alternatif yakıtların yıllık bazda farkı çalışma koşullarına göre maliyet hesaplamaları yapılmıştır. Ayrıca karbondioksit salınım değerleri elde edilmiştir. Referans olarak alınan gemi \%100' lük yük durumunda 5975 kw' lık bir güç çıkışına sahip bir dizel makineye sahiptir. Ele alınan bu geminin dizel yakıta alternatif olarak LNG, LPG, Metanol yakıtlarını kullanarak ne gibi maliyetlere sahip olacağı farklı yük durumları ve farklı yıllık çalışma saati koşullarına göre hesaplanmıştır. Bu hesaplamalarla birlikte hangi yakıtın daha hesaplı ve daha çevreci olabileceği incelenmiştir.

Anahtar Kelimeler: Alternatif Yakıt, Yıllık Karbondioksit Salınımı, Maliyet, Emisyon, Taşımacılık

Submitted: $17.09 .2020 \bullet$ Accepted: 20.10 .2020

1 Corresponding author: Tarik Kocal / Yıldız Technical University, Department of Marine Engineering Operations, Istanbul, Turkey E-mail: tkocal@yildiz.edu.tr ORCID: T.K. 0000-0002-3528-2437

Citation: Kocal, T. (2020). Examination of the operating costs and environmental impact of alternative fuels used in ships. Journal of Transportation and Logistics, 5(2), 83-91. https://doi.org/10.26650/JTL.2020.0020 


\section{Introduction}

In this study, the effect the type of fuel used on ship management cost was calculated. These costs were examined and compared according to different fuel types and different load conditions annually. Depending on the fuel consumption, the ship's annual carbon emission was observed for different fuels.

In previous studies, Iannccone and his colleagues explored the sustainability of innovative ship fuel systems based on LNG fuel use. As a result of their research, they concluded that LNG fuel system technologies are more sustainable in terms of their impact on the environment, economic feasibility and safety than conventional marine fuel technologies (Iannaccone, Landucci, Tugnoli, Salzano \& Cozzani, 2020).

Ammar discussed the environmental and economic effects of fuels by addressing the methanol-diesel dual-fuel ship engine in his study. This research established that methanol reduced NOx, SOx, CO, CO2, and PM emissions and made economic gains (Ammar, 2019).

In their paper, Schinas and Butler proposed a methodology for evaluating the commercial incentives needed to promote LNG as a marine fuel. They discussed the challenges preventing LNG from being adopted as a marine fuel (Schinas \& Butler, 2016).

Helgason and his colleagues compared Conventional Methanol, renewable methanol, and heavy fuel oil fuels in terms of their costs in their study (Helgason, Cook \& Davíðsdóttir, 2020). During this research, these stages were used:

- The existing main engine of the ship with a $5850 \mathrm{~kW}$ max power is the MAKITA MITSUI MAN B\&W 6S42MC.

- LNG, LPG, Butane, LPG Propane, and Methanol are alternative fuels to diesel fuel.

- Lower thermal values of the specified fuels are held in accord with ISO 8217 fuel standards.

- Using the verified specific fuel consumption specified in the main engine operator's manual, the amount of diesel fuel to be burned to obtain the desired power is calculated.

- This operation was repeated for $50 \%, 75 \%, 85 \%$ and $100 \%$ load conditions of ship and diesel fuel consumption was found according to 2000, 4000, and 6000 working hours in one year.

- To have the same brake power the mass that must be burned for the alternative fuel types was calculated.

- World market prices of specified fuels were researched, and these fuel's price averages of Asia, Europe, and America were taken to examine the cost according to the main engine, load and work hours situations.

- The referenced ship's carbon emission was calculated annually.

- At the end of the examination, alternative fuel costs wereanalyzed and carbon emissions were examined and compared. 


\section{Calculations Values}

Table 1. Lower heat values of alternative fuels ("Alternative Fuel Properties", 2019)

\begin{tabular}{|l|c|c|}
\hline Type of fuel & Reference & Lower Calorific Value (kj/kg) \\
\hline Diesel & ISO 8217 Grades & 42700 \\
\hline Liquefied Petroleum & Propane & 46300 \\
\hline Gas (LPG) & Butane & 45700 \\
\hline Liquefied Natural Gas (LNG) & & 48000 \\
\hline Methanol & & 19900 \\
\hline
\end{tabular}

The lower heat value is heat energy is when water is in the steam phase in a combustion reaction. In Table 1, the lower heat values of diesel, LPG, LNG, and Methanol are given.

Table 2. Market values of using fuels ("Diesel, LNG, Methanol and LPG Fuel Prices", 2019)

\begin{tabular}{|l|c|c|c|c|c|}
\hline Regions & $\begin{array}{c}\text { Methanol (\$/ } \\
\text { Ton) }\end{array}$ & $\begin{array}{c}\text { LNG } \\
\text { (\$/Ton) }\end{array}$ & $\begin{array}{c}\text { LPG Propane } \\
\text { (\$/Ton) }\end{array}$ & $\begin{array}{c}\text { LPG Butane } \\
\text { (\$/Ton) }\end{array}$ & Diesel (\$/Ton) \\
\hline America & 432 & 142,5 & 110 & 100 & 730 \\
\hline Europe & 360 & 512,5 & 470 & 450 & 690 \\
\hline Asia & 370 & 580,5 & 535 & 515 & 770 \\
\hline
\end{tabular}

Market prices of fuels were taken on April 26, 2019. Table 2 shows average fuel prices from 5 different ports in the USA, Europe, and Asia.

Table 3. Power and Specific Fuel Consumption Based on Load Condition of Reference Ship [9]

\begin{tabular}{|l|c|c|}
\hline LOAD & $\mathbf{P}(\mathbf{k w )}$ & SFOC(g/kwh) \\
\hline $50 \%$ & 2925 & 177,3 \\
\hline $75 \%$ & 4391 & 172,4 \\
\hline $85 \%$ & 5000 & 172,8 \\
\hline $100 \%$ & 5861 & 173,8 \\
\hline
\end{tabular}

Specific Fuel Consumption values based on the main engine load condition to be calculated are shown in Table 3. Also, carbon dioxide amounts as a result of combustion of all fuels are given in Table 4.

Table 4. $\mathrm{CO}_{2}$ emission values of fuels ("CO2 Emission Values of Fuels", 2019).

\begin{tabular}{|l|c|c|c|c|c|}
\hline & METHANOL & LNG & LPG PROPANE & LPG BUTANE & DİESEL \\
\hline $\mathrm{CO}_{2}\left(\mathrm{kgCO}_{2} / \mathrm{kgFUEL}\right)$ & 1,37 & 2,75 & 2,99 & 3,03 & 3,2 \\
\hline
\end{tabular}

\section{Calculations \& Evaluations}

The calculation of the fuel consumption of the main engine that we evaluate was taken from the main engine operator's manual which is specific fuel consumption(SFOC) values. The equation (1) is below,

$S F O C=\frac{\dot{m}}{P}$ 
With the mass flow rate, total fuel consumption was calculated in 2000, 4000 and 6000 working hours running situations in a year. Fuel consumption for diesel and LNG fuels are given in Table 5 .

Table 5. Diesel and LNG Fuel Consumptions

\begin{tabular}{|l|c|c|c|}
\hline & DİESEL & LNG (\%95 LNG) & LNG (\%5 DO) \\
\hline LOAD & 2000 hour (ton/year) & 2000 hour (ton/year) & 2000 hour (ton/year) \\
\hline $50 \%$ & 1037,21 & 876,55 & 51,86 \\
\hline $75 \%$ & 1514,02 & 1279,50 & 75,70 \\
\hline $85 \%$ & 1728,00 & 1460,34 & 86,40 \\
\hline $100 \%$ & 2037,28 & 1721,72 & 101,86 \\
\hline LOAD & 4000 hour (ton/year) & 4000 hour (ton/year) & 4000 hour (ton/year) \\
\hline $50 \%$ & 2074,41 & 1753,09 & 103,72 \\
\hline $75 \%$ & 3028,03 & 2559,00 & 151,40 \\
\hline $85 \%$ & 3456,00 & 2920,68 & 172,80 \\
\hline $100 \%$ & 4074,57 & 3443,43 & 203,73 \\
\hline LOAD & 6000 hour (ton/year) & 6000 hour (ton/year) & 6000 hour (ton/year) \\
\hline $50 \%$ & 3111,62 & 2629,64 & 155,58 \\
\hline $75 \%$ & 4542,05 & 3838,51 & 227,10 \\
\hline $85 \%$ & 5184,00 & 4381,02 & 259,20 \\
\hline $100 \%$ & 6111,85 & 5165,15 & 305,59 \\
\hline
\end{tabular}

LNG fuel consumption is based on diesel fuel consumption by diesel fuel burned multiplied lower heat energy of diesel fuel then divided by lower heat energy of LNG. The reason for getting 95\% LNG fuel 5\% diesel fuel in the calculations is that the petroleum fuels produced by liquefying from the gaseous state are not appropriate for the first operation of the main engine and the maneuvering circumstances. In other words, diesel fuel use

Table 6. Propane and LPG Butane Fuel Consumptions

\begin{tabular}{|l|c|c|c|c|}
\hline & LPG PROPANE & $\begin{array}{c}\text { LPG PROPANE } \\
\mathbf{( \% 5} \mathbf{D O})\end{array}$ & LPG BUTANE & $\begin{array}{c}\text { LPG BUTANE } \\
(\% 5 \text { DO) }\end{array}$ \\
\hline LOAD & 2000 hour (ton/year) & 2000 hour (ton/year) & 2000 hour (ton/year) & 2000 hour (ton/year) \\
\hline $50 \%$ & 908,73 & 51,86 & 920,66 & 51,86 \\
\hline $75 \%$ & 1326,48 & 75,70 & 1343,90 & 75,70 \\
\hline $85 \%$ & 1513,96 & 86,40 & 1533,84 & 86,40 \\
\hline $100 \%$ & 1784,93 & 101,86 & 1808,37 & 101,86 \\
\hline LOAD & 4000 hour (ton/year) & 4000 hour (ton/year) & 4000 hour (ton/year) & 4000 hour (ton/year) \\
\hline $50 \%$ & 1817,46 & 103,72 & 1841,32 & 103,72 \\
\hline $75 \%$ & 2652,96 & 151,40 & 2687,79 & 151,40 \\
\hline $85 \%$ & 3027,92 & 172,80 & 3067,67 & 172,80 \\
\hline $100 \%$ & 3569,87 & 203,73 & 3616,74 & 203,73 \\
\hline LOAD & 6000 hour (ton/year) & 6000 hour (ton/year) & 6000 hour (ton/year) & 6000 hour (ton/year) \\
\hline $50 \%$ & 2726,19 & 155,58 & 2761,98 & 155,58 \\
\hline $75 \%$ & 3979,44 & 227,10 & 4031,69 & 227,10 \\
\hline $85 \%$ & 4541,88 & 259,20 & 4601,51 & 259,20 \\
\hline $100 \%$ & 5354,80 & 305,59 & 5425,10 & 305,59 \\
\hline
\end{tabular}


while starting the main engine and in maneuvering circumstances. LPG Propane, LPG Butane, and Methanol fuels are given in Table 6 and Table 7 according to the main engine's loading situations and operation hours.

Table 7. Methanol Fuel Consumption

\begin{tabular}{|l|c|c|}
\hline & METHANOL & METHANOL (\%5 DO) \\
\hline LOAD & 2000 hour (ton/year) & 2000 hour (ton/year) \\
\hline $50 \%$ & 2114,28 & 51,86 \\
\hline $75 \%$ & 3086,24 & 75,70 \\
\hline $85 \%$ & 3522,43 & 86,40 \\
\hline $100 \%$ & 4152,88 & 101,86 \\
\hline LOAD & 4000 hour (ton/year) & 4000 hour (ton/year) \\
\hline $50 \%$ & 4228,56 & 103,72 \\
\hline $75 \%$ & 6172,47 & 151,40 \\
\hline $85 \%$ & 7044,86 & 172,80 \\
\hline $100 \%$ & 8305,77 & 203,73 \\
\hline LOAD & 6000 hour (ton/year) & 6000 hour (ton/year) \\
\hline $50 \%$ & 6342,85 & 155,58 \\
\hline $75 \%$ & 9258,71 & 227,10 \\
\hline $85 \%$ & 10567,28 & 259,20 \\
\hline $100 \%$ & 12458,65 & 305,59 \\
\hline
\end{tabular}

When the tables are analyzed, LPG and LNG fuels, which can be used as an alternative to diesel fuel have less fuel consumption compared to diesel fuel. LNG fuel consumption is starting to be more common in the usage area of ships due to being environment-friendly, $12 \%$ less than diesel fuel consumption. LNG fuel usage has a terrific advantage in terms of cost and environmental factors, but due to the IMO's standards, the tanks that are used for the storage of LNG fuel are most costly than diesel fuel tanks.

Usage of LPG Propane and Butane too also provides cost efficiency when compared to diesel fuel. Methanol is identified as having the highest fuel consumption compared to other alternative fuel resources. The reason for this is the combustion of $1 \mathrm{gr}$ methanol exposes less energy compared to other fuels. To provide the required power we must burn more methanol than other fuels.

When the emission values of the discussed main engine were analyzed, it was seen that the emission values of all fuels were lower than diesel fuel. $\mathrm{CO}_{2}$ emissions of the referenced ship are given in Table 8. When we examined $\mathrm{CO}_{2}$ emissions of the possible alternatives to diesel fuel, Methanol seems like the most environmentally friendly fuel. But, when we analyze the reference ship's carbon emissions values on an annual basis, it shows that Methanol comes after LNG and LPG derivatives. The reason for this is that Methanol fuel has twice the consumption compared to LNG and LPG derivatives in order to provide the desired energy. That's why carbon emission increases. 
Table 8. $\mathrm{CO}_{2}$ Emission Values of reference ship

\begin{tabular}{|l|c|c|c|c|c|}
\hline & DiESEL & LNG & $\begin{array}{c}\text { LPG } \\
\text { PROPANE }\end{array}$ & $\begin{array}{c}\text { LPG } \\
\text { BUTANE }\end{array}$ & METHANOL \\
\hline LOAD & $\begin{array}{c}2000 \text { hour (ton/ } \\
\text { year) }\end{array}$ & $\begin{array}{c}2000 \text { hour (ton/ } \\
\text { year) }\end{array}$ & $\begin{array}{c}2000 \text { hour (ton/ } \\
\text { year) }\end{array}$ & $\begin{array}{c}2000 \text { hour } \\
\text { (ton/year) }\end{array}$ & $\begin{array}{c}2000 \text { hour (ton/ } \\
\text { year) }\end{array}$ \\
\hline $50 \%$ & 3319,05 & 2576,45 & 2883,05 & 2955,55 & 3062,51 \\
\hline $75 \%$ & 4844,85 & 3760,87 & 4208,42 & 4314,25 & 4470,38 \\
\hline $85 \%$ & 5529,60 & 4292,41 & 4803,21 & 4924 & 5102,20 \\
\hline $100 \%$ & 6519,307 & 5060,68 & 5662,91 & 5805,31 & 6015,41 \\
\hline LOAD & 4000 hour & 4000 hour & 4000 hour & 4000 hour & 4000 hour \\
(ton/year) & (ton/year) & (ton/year) & (ton/year) & (ton/year) \\
\hline $50 \%$ & 6638,11 & 5152,91 & 5766,11 & 5911,11 & 6125,03 \\
\hline $75 \%$ & 9689,70 & 7521,74 & 8416,84 & 8628,50 & 8940,77 \\
\hline $85 \%$ & 11059,20 & 8584,83 & 9606,43 & 9848 & 10204,41 \\
\hline $100 \%$ & 13038,61 & 10121,37 & 11325,83 & 11610,63 & 12030,83 \\
\hline LOAD & 6000 hour & 6000 hour & 6000 hour & 6000 saat & 6000 hour \\
(ton/year) & (ton/year) & (ton/year) & (ton/y1) & (ton/year) \\
\hline $50 \%$ & 9957,16 & 7729,36 & 8649,17 & 8866,66 & 9187,55 \\
\hline $75 \%$ & 14534,56 & 11282,61 & 12625,26 & 12942,75 & 13411,15 \\
\hline $85 \%$ & 16588,80 & 12877,24 & 5371,31 & 14772,01 & 15306,61 \\
\hline $100 \%$ & 19557,92 & 15182,06 & 16988,74 & 17415,95 & 18046,25 \\
\hline
\end{tabular}

When Table 8 examined, LNG is seen as the most environmentally friendly fuel after methanol. Although LNG fuel has a ratio close to the LPG Propane and Butane fuels, it has a significant difference when considered as the annual $\mathrm{CO}_{2}$ emission of a ship. It was calculated that the reference ship produces an average of 5000 tons less carbon compared to LPG derivatives in LNG fuel at 6000 working hours per year at $85 \%$ load. According to calculations made, LPG Propane is the second most environmentally friendly fuel and LPG Butane is the third.

Table 9. Fuel Cost of American Region

\begin{tabular}{|c|c|c|c|c|c|}
\hline & DİESEL & LNG & $\begin{array}{c}\text { LPG } \\
\text { PROPANE }\end{array}$ & LPG BUTANE & METHANOL \\
\hline LOAD & $\begin{array}{l}2000 \text { hour } \\
\text { (\$/year) }\end{array}$ & $\begin{array}{l}2000 \text { hour } \\
\text { (\$/year) }\end{array}$ & $\begin{array}{l}2000 \text { hour } \\
\text { (\$/year) }\end{array}$ & $\begin{array}{l}2000 \text { hour } \\
\text { (\$/year) }\end{array}$ & $\begin{array}{l}2000 \text { hour } \\
\text { (\$/year) }\end{array}$ \\
\hline $50 \%$ & 757159,65 & 162765,82 & 137818,33 & 129924,11 & 951228 \\
\hline $75 \%$ & 1105232,26 & 237590,63 & 201174,57 & 189651,31 & 1388515,45 \\
\hline $85 \%$ & 1261440 & 271170,45 & 229607,53 & 216455,63 & 1584760,95 \\
\hline $100 \%$ & 1487217,02 & 319705,50 & 270703,50 & 255197,63 & 1868407,12 \\
\hline LOAD & $\begin{array}{l}4000 \text { hour } \\
\text { (\$/year) }\end{array}$ & $\begin{array}{l}4000 \text { hour } \\
\text { (\$/year) }\end{array}$ & $\begin{array}{l}4000 \text { hour } \\
\text { (\$/year) }\end{array}$ & $\begin{array}{l}4000 \text { hour } \\
\text { (\$/year) }\end{array}$ & $\begin{array}{l}4000 \text { hour } \\
(\$ / \text { year })\end{array}$ \\
\hline $50 \%$ & 1514319,30 & 325531,65 & 275636,66 & 259848,22 & 1902456 \\
\hline $75 \%$ & 2210464,52 & 475181,26 & 402349,14 & 379302,62 & 2777030,91 \\
\hline $85 \%$ & 2522880 & 542340,9 & 459215,06 & 432911,26 & 3169521,91 \\
\hline $100 \%$ & 2974434,05 & 639411,00 & 541407,01 & 510395,26 & 3736814,24 \\
\hline LOAD & $\begin{array}{l}6000 \text { hour } \\
\text { (\$/year) }\end{array}$ & $\begin{array}{l}6000 \text { hour } \\
\text { (\$/year) }\end{array}$ & $\begin{array}{c}6000 \text { hour } \\
\text { (\$/year) }\end{array}$ & $\begin{array}{l}6000 \text { hour } \\
\text { (\$/year) }\end{array}$ & $\begin{array}{l}6000 \text { hour } \\
\text { (\$/year) }\end{array}$ \\
\hline $50 \%$ & 2271478,95 & 488297,47 & 413455 & 389772,33 & 2853684 \\
\hline $75 \%$ & 3315696,79 & 712771,90 & 603523,72 & 568953,93 & 4165546,37 \\
\hline $85 \%$ & 3784320 & 813511,35 & 688822,60 & 649366,89 & 4754282,87 \\
\hline $100 \%$ & 4461651,08 & 959116,51 & 812110,52 & 765592,89 & 5605221,36 \\
\hline
\end{tabular}


Diesel and other alternative fuels in respect of regions are given on an annual basis in Table 9, Table 10, and Table 11 depending on the main engine loading.

Table 10. Fuel Cost of Europe Region

\begin{tabular}{|c|c|c|c|c|c|}
\hline & DİESEL & LNG & $\begin{array}{c}\text { LPG } \\
\text { PROPANE }\end{array}$ & LPG BUTANE & METHANOL \\
\hline LOAD & $\begin{array}{l}2000 \text { hour } \\
\text { (\$/year) }\end{array}$ & $\begin{array}{l}2000 \text { hour } \\
\text { (\$/year) }\end{array}$ & $\begin{array}{l}2000 \text { hour } \\
\text { (\$/year) }\end{array}$ & $\begin{array}{l}2000 \text { hour } \\
\text { (\$/year) }\end{array}$ & $\begin{array}{l}2000 \text { hour } \\
\text { (\$/year) }\end{array}$ \\
\hline $50 \%$ & 715671,45 & 485013,53 & 462886,89 & 450081,15 & 796925,25 \\
\hline $75 \%$ & 1044671,59 & 707978,30 & 675679,86 & 656987,21 & 1163278,45 \\
\hline $85 \%$ & 1192320 & 808040,25 & 771176,91 & 749842,34 & 1327690,13 \\
\hline $100 \%$ & 1405725,68 & 952666,174 & 909204,90 & 884051,80 & 1565324,84 \\
\hline LOAD & $\begin{array}{l}4000 \text { hour } \\
\text { (\$/year) }\end{array}$ & $\begin{array}{l}4000 \text { hour } \\
\text { (\$/year) }\end{array}$ & $\begin{array}{l}4000 \text { hour } \\
\text { (\$/year) }\end{array}$ & $\begin{array}{l}4000 \text { hour } \\
\text { (\$/year) }\end{array}$ & $\begin{array}{l}4000 \text { hour } \\
\text { (\$/year) }\end{array}$ \\
\hline $50 \%$ & 1431342,90 & 970027,0689 & 925773,78 & 900162,30 & 1593850,51 \\
\hline $75 \%$ & 2089343,18 & 1415956,61 & 1351359,79 & 1313974,43 & 2326556,90 \\
\hline $85 \%$ & 2384640 & 1616080,50 & 1542353,83 & 1499684,69 & 2655380,26 \\
\hline $100 \%$ & 2811451,36 & 1905332,34 & 1818409,81 & 1768103,60 & 3130649,68 \\
\hline LOAD & $\begin{array}{l}6000 \text { hour } \\
\text { (\$/year) }\end{array}$ & $\begin{array}{l}6000 \text { hour } \\
\text { (\$/year) }\end{array}$ & $\begin{array}{l}6000 \text { hour } \\
\text { (\$/year) }\end{array}$ & $\begin{array}{l}6000 \text { hour } \\
(\$ / \text { year })\end{array}$ & $\begin{array}{c}6000 \text { hour (\$/ } \\
\text { year) }\end{array}$ \\
\hline $50 \%$ & 2147014,35 & 1455040,60 & 1388660,68 & 1350243,45 & 2390775,76 \\
\hline $75 \%$ & 3134014,77 & 2123934,91 & 2027039,59 & 1970961,64 & 3489835,35 \\
\hline $85 \%$ & 3576960 & 2424120,75 & 2313530,74 & 2249527,03 & 3983070,39 \\
\hline $100 \%$ & 4217177,05 & 2857998,52 & 2727614,72 & 2652155,40 & 4695974,53 \\
\hline
\end{tabular}

Table 11. Fuel Cost of Asian Region

\begin{tabular}{|c|c|c|c|c|c|}
\hline & DİESEL & LNG & $\begin{array}{c}\text { LPG } \\
\text { PROPANE }\end{array}$ & LPG BUTANE & METHANOL \\
\hline LOAD & $\begin{array}{l}2000 \text { hour } \\
\text { (\$/year) }\end{array}$ & $\begin{array}{l}2000 \text { hour } \\
\text { (\$/year) }\end{array}$ & $\begin{array}{l}2000 \text { hour } \\
\text { (\$/year) }\end{array}$ & $\begin{array}{l}2000 \text { hour } \\
\text { (\$/year) }\end{array}$ & $\begin{array}{l}2000 \text { hour } \\
\text { (\$/year) }\end{array}$ \\
\hline $50 \%$ & 798647,85 & 548767,50 & 526103,19 & 514072,95 & 822216,90 \\
\hline $75 \%$ & 1165792,93 & 801040,50 & 767957,22 & 750396,58 & 1200196,87 \\
\hline $85 \%$ & 1330560 & 914255,37 & 876496,27 & 856453,70 & 1369826,41 \\
\hline $100 \%$ & 1568708,37 & 1077892,05 & 1033374,70 & 1009744,84 & 1615002,82 \\
\hline LOAD & $\begin{array}{l}4000 \text { hour } \\
\text { (\$/year) }\end{array}$ & $\begin{array}{l}4000 \text { hour } \\
\text { (\$/year) }\end{array}$ & $\begin{array}{l}4000 \text { hour } \\
\text { (\$/year) }\end{array}$ & $\begin{array}{l}4000 \text { hour } \\
\text { (\$/year) }\end{array}$ & $\begin{array}{l}4000 \text { hour } \\
\text { (\$/year) }\end{array}$ \\
\hline $50 \%$ & 1597295,70 & 1097535 & 1052206,38 & 1028145,91 & 1644433,80 \\
\hline $75 \%$ & 2331585,87 & 1602081 & 1535914,45 & 1500793,17 & 2400393,75 \\
\hline $85 \%$ & 2661120 & 1828510,74 & 1752992,55 & 1712907,41 & 2739652,82 \\
\hline $100 \%$ & 3137416,74 & 2155784,11 & 2066749,40 & 2019489,68 & 3230005,65 \\
\hline LOAD & $\begin{array}{c}6000 \text { hour } \\
\text { (\$/year) }\end{array}$ & $\begin{array}{l}6000 \text { hour } \\
\text { (\$/year) }\end{array}$ & $\begin{array}{l}6000 \text { hour } \\
\text { (\$/year) }\end{array}$ & $\begin{array}{l}6000 \text { hour } \\
\text { (\$/year) }\end{array}$ & $\begin{array}{l}6000 \text { hour } \\
\text { (\$/year) }\end{array}$ \\
\hline $50 \%$ & 2395943,55 & 1646302,50 & 1578309,58 & 1542218,86 & 2466650,70 \\
\hline $75 \%$ & 3497378,80 & 2403121,51 & 2303871,68 & 2251189,75 & 3600590,62 \\
\hline $85 \%$ & 3991680 & 2742766,11 & 2629488,82 & 2569361,12 & 4109479,23 \\
\hline $100 \%$ & 4706125,11 & 3233676,16 & 3100124,11 & 3029234,53 & 4845008,47 \\
\hline
\end{tabular}

When LPG consumption costs are examined, LPG fuel is seen as a better alternative compared to Diesel fuel. 


\section{Conclusion}

In this study, cost computations and carbon dioxide emission values of alternative fuels that can be used in ships are calculated according to different operational situations on an annual basis. The ship taken as a reference has a diesel engine with a $5850 \mathrm{~kW}$ brake power at $100 \%$ load condition. The kind of costs involved in the case of using LNG, LPG, and Methanol fuels as an alternative to diesel fuel were calculated according to different load conditions, different annual working hour circumstances, and different regions. It was seen which fuel is more economical and more environmentally friendly with the help of these calculations. The benefits that can be gained as a result of the use of alternative fuels that can be replaced with diesel fuel were observed. In addition to these situations, carbon emissions of alternative fuels were calculated and their effects on the environment were observed.

The following results were obtained in this study:

1) When we examined LNG fuel, we notice that carbon emission is the most important point. LNG fuel has less $\mathrm{CO}_{2}$ emission values compared to the other fuels named as alternative fuels. When considering research done, LNG fuel also has a lower release of sulfur and nitrogen than the other fuels. Looking at the value of the LNG in the world market, it is seen that it is the 3rd cheapest in America, the 4th cheapest in Asia and in Europe. When the reference ship operates with LNG fuel at the $85 \%$ load in the America region for 2000 working hours per year, it is concluded that it has less fuel consumption of approximately $\$ 990,000$ compared to Diesel fuel. In terms of the annual consumption of LNG fuel in the Europe and Asia regions, it is concluded that the reference ship operating at $85 \%$ for 2000 hours per year has a lower cost of about $\$ 384,000$ when compared to diesel fuel in Europe and $\$ 416,000$ in the Asian region.

2) Looking at the LPG Butane fuel's price in the world market, it is seen that it is the cheapest fuel in all regions. When the carbon emission values of LPG butane fuel examined, it is seen that it is higher than the other alternative fuels. But it doesn't mean LPG butane is not environmentally friendly. It was calculated that LPG butane fuel emits 1814 less $\mathrm{CO}_{2}$ compared to diesel fuel in terms of $85 \%$ load at 6000 working hours per year. Turning to the fuel costs calculation, LPG Butane in conditions of $85 \%$ load with 2000 hours per year saved \$1 million compared to Diesel in the America region and $\$ 442,000$ in the European region and $\$ 474,000$ in the Asian region.

3) When we look at the value of the LPG Propane in the world market, it is seen that it is the 2nd cheapest fuel in the continent of America and the 3rd cheapest fuel in Asia and in Europe. When we compare the $\mathrm{CO}_{2}$ emissions of alternative fuels, LPG Propane is the third lowest, after Methanol and LNG. LPG Propane is the second most environmentally friendly fuel according to calculations of $\mathrm{CO}_{2}$ emission of the reference ship. If the reference ship works 2000 working hours with a $85 \%$ load, it will cause $\$ 1,031$ millionsaving in the USA, $\$ 421,000$ savings in Europe, and $\$ 454,000$ savings in Asia. 
Peer-review: Externally peer-reviewed.

Conflict of Interest: The author has no conflict of interest to declare.

Grant Support: The author declared that this study has received no financial support.

Hakem Değerlendirmesi: Dış bağımsız.

Çıkar Çatışması: Yazar çıkar çatışması bildirmemiştir.

Finansal Destek: Yazar bu çalışma için finansal destek almadığını beyan etmiştir.

\section{References}

Alternative Fuel Properties. (2019). Website: https://afdc.energy.gov/fuels/properties

Ammar N. R., (2019) “An environmental and economic analysis of methanol fuel for a cellular container ship". Transport Research Part, 69, 66-76.

$\mathrm{CO}_{2}$ Emission Values of Fuels. (2019). Website: https://www.engineeringtoolbox.com /co2-emissionfuels-d_1085.html

Diesel and LNG Fuel Prices. (2019). Website: https://shipandbunker.com/prices

Helgason R., Cook D. and Davíðsdóttir L. (2020) “An evaluation of the cost-competitiveness of maritime fuels - a comparison of heavy fuel oil and methanol (renewable and natural gas) in Iceland". Sustainable Production and Consumption, 23, 236-248.

Iannaccone T., Landucci G., Tugnoli A. and Salzano E and Cozzani., (2020) "Sustainability of cruise ship fuel systems: Comparison among LNG and diesel technologies” Journal of Cleaner Production, Vol. 260, 1-13.

LPG Fuel Prices. (2019). Website: http://3mgas.vn/news/saudi-aramco-lpg-prices-per-metric-tonne-mt-n146. html

Makita Mitsui Man B\&W Diesel Engine Instruction Manual For 6S42MC

Methanol Fuel Prices. (2019). Website: https://www.methanex.com/our-business /pricing

Schinas O. and Butler M., (2016) "Feasibility and commercial considerations of LNG-fueled ships". Ocean Engineering, 122, 84-96. 
